\title{
A Reasonable Possibility of Refoulement: The Inadequacies of Procedures to Protect Vulnerable Noncitizens from Return to Persecution, Torture, or Death
}

Lexie Marilyn Ford

Texas A\&M University School of Law (Student), lexie.ford.5010@tamu.edu

Follow this and additional works at: https://scholarship.law.tamu.edu/lawreview

Part of the Constitutional Law Commons, and the Immigration Law Commons

\section{Recommended Citation}

Lexie Marilyn Ford, A Reasonable Possibility of Refoulement: The Inadequacies of Procedures to Protect Vulnerable Noncitizens from Return to Persecution, Torture, or Death, 9 Tex. A\&M L. Rev. 209 (2021). Available at: https://doi.org/10.37419/LR.V9.I1.5 


\title{
COMMENTS
}

\section{A REASONABLE POSSIBILITY OF REFOULEMENT: THE INADEQUACIES OF PROCEDURES TO PROTECT VULNERABLE NONCITIZENS FROM RETURN TO PERSECUTION, TORTURE, OR DEATH}

\author{
by: Lexie M. Ford*
}

\begin{abstract}
Due primarily to increases in individuals fleeing violence and turmoil in Central America, over $40 \%$ of noncitizens arriving in the United States are put on a fast-track removal process and subsequently claim fear of returning to their home countries. A decade ago, the number was only 5\%. This influx of asylum-seekers at the border has led to tension between those who wish to protect them and those who view such migrants as "invaders." In 2019 and 2020, the Trump Administration proffered sweeping regulatory changes with the aim to substantively and procedurally restrict noncitizens' access to protection from persecution and torture in their home countries. Although not all of these proposals may ultimately go into effect, it is vital to explore the legality of such provisions lest they reappear in subsequent administrations.

Pursuant to domestic and international law, the United States is subject to the non-refoulement obligation, which prohibits forcibly returning a refugee to a country that threatens their life or freedom. All humans have the fundamental right to not be returned to a country where they will be persecuted or tortured, regardless of their legal status in the country where they seek protection. In the United States, noncitizens facing qualifying persecution or torture upon return to their home countries are entitled to protection in the form of statutory withholding of removal ("withholding") or withholding or deferral of removal pursuant to the Convention Against Torture ("CAT protection").

This Comment argues that noncitizens vindicating their non-refoulement rights by seeking withholding or CAT protection must receive stronger procedural protections because of the fundamental interests at stake. Specifically, two issues are addressed. First, the use of the "reasonable possibility" standard of proof at the fear screening stage, a practice expanded in recent years, is inappropriate and a violation of the non-refoulement obligation. This standard is suited for final determinations on the merits, not threshold screenings. Because of the well-documented problems with fear screenings, even absent an increased standard of proof, this practice would result in an impermissible risk that individuals with valid claims would be returned to face persecution, torture, or even death without ever being fairly heard. Second, the unique position of these noncitizens, from legal and humanitarian perspectives, should entitle them to Constitutional Due Process Clause protections. Because their right to non-refoulement is not subject to the discretion of the Executive, the denial of due process cannot be justified by the "entry fiction," the legal doctrine that gives certain noncitizens inside the United States limited constitutional protections because the law considers them to be detained at the border.
\end{abstract}

DOI: https://doi.org/10.37419/LR.V9.I1.5

* J.D. Candidate, Texas A\&M University School of Law, May 2022. I would like to thank my advisor, Professor Fatma Marouf, for her guidance throughout the writ- 
TABLE OF CONTENTS

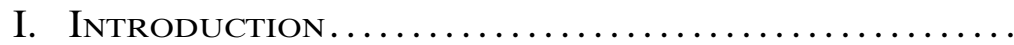

II. Background: Rights, Relief, and Procedural Hurdles for Asylum-SeEkers .................. 214

A. The Non-Refoulement Obligation: Protecting the Most Fundamental Human Right.................

B. Overview of Asylum, Withholding of Removal, and the Convention Against Torture ..................

C. Procedural Barriers: Expedited Removal Proceedings and Fear Screening Interviews..................

III. An Impermissible Threat to the Fulfillment of Non-Refoulement Obligations: Use of the Reasonable Possibility Standard in Initial Fear

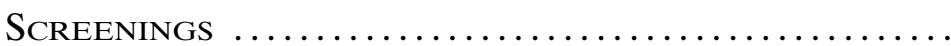

A. Recent Attempts to Radically Change Asylum Regulations .............................. 221

B. The "Reasonable Possibility" Standard Explained... 222

C. Same Standard, Vastly Different Protections and Resources: A Comparison of the Asylum Merits Hearing and the Fear Screening Interview Setting ...

1. Procedural Safeguards at the Asylum Merits Hearing ..............................

2. Problems with the Fear Screening Interview Setting ............................ 226

3. Lack of Judicial Review ................... 229

D. Analysis: Expanded Use of the Reasonable Possibility Standard Violates the Non-Refoulement Obligation ................................

IV. The Dire Need for Full Due Process Protections for Noncitizens Seeking Protection FROM RefOUlement .......................... 232

A. The Entry Fiction Should Not Apply to Individuals Seeking Withholding and CAT Protection...........

B. Application of the Mathews Due Process Test to the Proposed Fear Screening Procedures .............. 234

V. Conclusion ................................... 236

ing process as well as the Texas A\&M Law Review editorial staff for their hard work and excellent editing. All mistakes are my own. I would also like to thank my family, especially Alexis and Finn for loving and supporting me, even on days I barely moved from my writing spot by the window. 


\section{INTRODUCTION}

Give me your tired, your poor,

Your huddled masses yearning to breathe free, The wretched refuse of your teeming shore. Send these, the homeless, tempest-tost to me, I lift my lamp beside the golden door! $!^{1}$

Admission to the United States has never been as simple or as altruistic of a process as the above inscription on the Statue of Liberty suggests. ${ }^{2}$ Previously, most individuals facing deportation had the opportunity to make their case in front of a judge, but that right began to disappear beginning in 1996 with over $80 \%$ of deportations being nonjudicial by $2013 .{ }^{3}$ Now, thanks to the process known as "expedited removal," many potential immigrants who arrive at the U.S. border without documentation are deported in as little as a single day without appearing before a judge and without a right to appeal. ${ }^{4}$ The only way to pause this swift removal process is to express a fear of persecution or torture in a particular country or an intent to apply for asylum, ${ }^{5}$ and even then, the procedural safeguards in place are vastly insufficient, which is the focus of this Comment.

Due primarily to increases in individuals fleeing violence and turmoil in Central America, over $40 \%$ of noncitizens arriving in the United States are put on a fast-track removal process and subsequently claim fear of returning to their home countries. ${ }^{6}$ A decade ago, the number was only $5 \% .{ }^{7}$ This influx of asylum-seekers ${ }^{8}$ at the

1. Emma Lazarus, The New Colossus, Poetry Found. (1883), https:// www.poetryfoundation.org/poems/46550/the-new-colossus [https://perma.cc/YVR59K9T] (poem inscribed on the Statue of Liberty).

2. See, e.g., John Higham, American Immigration Policy in Historical Perspective, 21 LaW \& ConTemp. Probs. 213, 213 (1956).

3. Sarah Stillman, When Deportation Is a Death Sentence, New Yorker (Jan. 8, 2018), https://www.newyorker.com/magazine/2018/01/15/when-deportation-is-a-deathsentence [https://perma.cc/FJ4K-G7J2]; see also Jennifer Lee Koh, Removal in the Shadows of Immigration Court, 90 S. CAL. L. Rev. 181, 184 (2017) (explaining that immigration officers issued $83 \%$ of removal orders issued in 2013 , "thus bypassing the immigration courts entirely").

4. Immigration and Nationality Act (INA) § 235, 8 U.S.C. $§ 1225$ (2020); HiLLEL R. Smith, Cong. Rsch. Serv., LSB10150, Immigration Laws Regulating the Admission And Exclusion of Aliens at the Border 2 (2020), https://fas.org/sgp/ crs/homesec/LSB10150.pdf [https://perma.cc/RCF2N2X2]; Fact Sheet: Expedited Removal, NAT'L IMMIGR. F. (June 4, 2019), https:/immigrationforum.org/article/factsheet-expedited-removal/ [https://perma.cc/8MXK-WS5C].

5. Sмiтh, supra note 4, at 2.

6. Asylum Eligibility and Procedural Modifications, 84 Fed. Reg. 33,829, 33,830-31 (July 16, 2019) (codified at 8 C.F.R. $\$ \S 208,1003,1208$ ).

7. $I d$.

8. References to "asylum-seekers" in this Comment refer to individuals seeking any kind of fear-based immigration relief, including statutory withholding of removal or protection pursuant to the Convention Against Torture. 
border has led to tension between those who wish to protect them ${ }^{9}$ and those who view such migrants as "invaders." 10

Regardless of political agenda, the United States is bound by the international law doctrine of non-refoulement, meaning that it may not return any individual to a country where their life or freedom is threatened. ${ }^{11}$ However, the procedures in place to ensure non-refoulement are minimal, and even these are not properly enforced. ${ }^{12}$ A 2014 American Civil Liberties Union report indicated that among interviewees who were removed without seeing an immigration judge, $55 \%$ "said they were not asked about fear of persecution or torture" while $40 \%$ of those who reported fear of return after being asked were "ordered deported without seeing an asylum officer."13 As a result of the flawed fear screening system, there are already numerous accounts of asylum-seekers being subsequently killed when returned to their countries of origin. ${ }^{14}$

In addition to this decades-long trend of turning away fearful migrants at the "golden door," regulatory changes in $2019^{15}$ and $2020^{16}$ have attempted ${ }^{17}$ to further narrow the proverbial door in ways that raise serious humanitarian concerns. ${ }^{18}$ Specifically, one proposal sug-

9. See, e.g., Elizabeth Cassidy \& Tiffany Lynch, U.S. Comm'n on Int'l Religious Freedom, Barriers to Protection: The Treatment of Asylum SeekERS IN EXPEDITED REMOVAl 4 (2016), https://www.uscirf.gov/sites/default/files/ Barriers\%20To\%20Protection.pdf [https://perma.cc/D43C-PR2M].

10. See, e.g., John Fritze, Trump Used Words Like 'Invasion' and 'Killer' to Discuss Immigrants at Rallies 500 Times: USA TODAY Analysis, USA ToDAY, https:// www.usatoday.com/story/news/politics/elections/2019/08/08/trump-immigrants-rhetoric-criticized-el-paso-dayton-shootings/1936742001 (Aug. 21, 2019, 10:18 AM) [https:// perma.cc/P45C-RBB7].

11. Office of the U.N. High Commissioner for Refugees (UNHCR), Introductory Note of Convention and Protocol Relating to the Status of Refugees 3 (Dec. 2010), https://www.unhcr.org/en-us/protection/basic/3b66c2aa10/conventionprotocol-relating-status-refugees.html [https://perma.cc/PT3G-J28N] [hereinafter UNHCR Introductory Note].

12. See infra Section III.C.2.

13. Stillman, supra note 3.

14. See, e.g., Kevin Sieff, When Death Awaits Deported Asylum Seekers, WAsH. Post (Dec. 26, 2018), https://www.washingtonpost.com/graphics/2018/world/whendeath-awaits-deported-asylum-seekers/ [https://perma.cc/5F72-QCNN]; Stillman, supra note 3.

15. Asylum Eligibility and Procedural Modifications, 84 Fed. Reg. 33,829, 33,830-31 (July 16, 2019) (codified at 8 C.F.R. $\$ \S 208,1003,1208$ ).

16. Procedures for Asylum and Withholding of Removal; Credible Fear and Reasonable Fear Review, 85 Fed. Reg. 80,274 (Dec. 11, 2020) (codified at 8 C.F.R. $\S \S 208$, $235,1003,1208,1235)$.

17. Some of the rules have been enjoined from going into effect. See Pangea Legal Servs. v. Dep't of Homeland Sec., 512 F. Supp. 3d 966 (N.D. Cal. 2021). See infra Section III.A for further discussion.

18. See, e.g., Amanda Holpuch, Trump Has Nearly Destroyed US Refugee Program, Experts Say, GuARDian (Sept. 28, 2019, 1:01 AM), https:// www.theguardian.com/world/2019/sep/27/trump-refugee-cap-asylum-program [https:// perma.cc/4EQC-Q887]; Heidi Altman et al., The Trump Administration's Checklist to Destroy the U.S. Asylum System, Nat'L Immigrant Just. CTr. (May 22, 2018), https:/ 
gested that noncitizens seeking protection from refoulement through statutory withholding of removal ("withholding") or withholding or deferral of removal pursuant to the Convention Against Torture ("CAT protection") would undergo initial fear screenings using the "reasonable possibility" standard. ${ }^{19}$ This standard of proof would require that these individuals demonstrate (a) "a reasonable possibility that [they] would be persecuted" on account of a protected ground in the country of removal or (b) "a reasonable possibility that [they] would be tortured in the country of removal." ${ }^{20}$ The standard of proof was previously the same as the current standard for seeking asylum: presenting a significant possibility of being able to establish qualifying persecution or torture. ${ }^{21}$ Given the circumstances of these interviews and the vulnerable positions of arriving asylum-seekers, both the reasonable possibility and the asylum standards are quite difficult burdens to meet. ${ }^{22}$ An additional proposal suggested that a negative fear finding at the interview stage become final unless the noncitizen were to affirmatively request review, whereas currently the finding is forwarded for review by an immigration judge ("IJ") unless the noncitizen affirmatively declines review. ${ }^{23}$

Despite the substantial risk that asylum officers will improperly apply the law and deny noncitizens seeking protection a chance to be fully heard, these procedural deficiencies cannot be adequately challenged because of the lack of judicial review of fear screening determinations ${ }^{24}$ and the refusal to afford constitutional due process rights to noncitizens seeking to vindicate their non-refoulement rights-even

/immigrantjustice.org/staff/blog/trump-administrations-checklist-destroy-us-asylumsystem [https://perma.cc/JN5P-JPG5]; Erika Guevara-Rosas, Trump's Efforts to End Asylum Are an All-Out Assault on Human Rights, AMNESTy InT'L (Feb. 27, 2020, 6:01 AM), https://www.amnesty.org/en/latest/news/2020/02/trumps-efforts-end-asylum-assault-human-rights [https://perma.cc/E37U-X6VA].

19. Procedures for Asylum and Withholding of Removal; Credible Fear and Reasonable Fear Review, 85 Fed. Reg. at 80,277.

20. $I d$.

21. $I d$.

22. See infra Section IV.B.

23. Procedures for Asylum and Withholding of Removal; Credible Fear and Reasonable Fear Review, 85 Fed. Reg. at 80,279 ("The Departments further amend 8 CFR 208.30(g) and 8 CFR 1208.30(g)(2), which address procedures for negative fear determinations for aliens in the expedited removal process. In 8 CFR 208.30(g)(1), the Departments treat an alien's refusal to indicate whether he or she desires review by an immigration judge as declining to request such review. Also, in 8 CFR 208.31, the Departments treat a refusal as declining to request review within the context of reasonable fear determinations."); Procedures for Asylum and Withholding of Removal; Credible Fear and Reasonable Fear Review, 85 Fed. Reg. 36,264, 36,273 (proposed June 15, 2020) ("Currently, 8 CFR 208.30(g) provides that when an alien receives notice of a negative determination, the asylum officer inquires whether the alien wishes to have an immigration judge review the decision. If that alien refuses to indicate whether he or she desires such review, DHS treats this as a request for review by an immigration judge.").

24. See infra Section III.C.3. 
though they are physically present in the United States and face deprivation of life and liberty by state actors. ${ }^{25}$

This Comment argues that noncitizens vindicating their nonrefoulement rights by seeking withholding or CAT protection must receive stronger procedural protections because of the fundamental interests at stake. Part II of this Comment provides an overview of the non-refoulement obligation, the categories of immigration relief available to individuals seeking fear-based protection, and the procedural barriers that stand in their way. Part III argues that using the reasonable possibility standard of proof in the fear screening context is a violation of the non-refoulement obligation. Section III.A gives an overview of the recent regulatory attempts to expand the use of this standard. Section III.B explains the standard in comparison with the "significant possibility" standard-the appropriate threshold screening standard. Section III.C highlights the differences between the fear screening setting and the asylum merits hearing to illustrate why the reasonable possibility standard is appropriate for one and not the other. Section III.D explains how the use of the reasonable possibility standard for fear screening is not only inappropriate-it is also a violation of the non-refoulement obligation. Finally, Part IV argues that noncitizens seeking withholding and CAT protection should be afforded full constitutional due process rights and applies the Mathews v. Eldridge due process test to show that using the reasonable possibility standard at the fear screening stage is unconstitutional.

\section{Background: Rights, Relief, and Procedural Hurdles FOR Asylum-SeEKers}

\section{A. The Non-Refoulement Obligation: Protecting the Most Fundamental Human Right}

Non-refoulement is an "international legal norm" introduced by the 1951 United Nations ("UN") Convention Relating to the Status of Refugees ("the Convention"). ${ }^{26}$ According to the Office of the United Nations High Commissioner for Refugees ("UNHCR"), "[t]he principle of non-refoulement is so fundamental that no reservations or derogations may be made to it. It provides that no one shall expel or return ('refouler') a refugee against his or her will, in any manner whatsoever, to a territory where he or she fears threats to life or freedom." ${ }^{27}$

25. See infra Section IV.A.

26. Jaya Ramji-Nogales, Non-Refoulement Under the Trump Administration, ASIL Insights (Dec. 3, 2019), https://www.asil.org/insights/volume/23/issue/11/nonrefoulement-under-trump-administration\#_edn1 [https://perma.cc/SDF2-BKAN]; United Nations Convention Relating to the Status of Refugees, art. 33, July 28, 1951, 189 U.N.T.S. 150 [hereinafter U.N. Convention].

27. UNHCR Introductory Note, supra note 11, at 3. 
While the United States did not join the Convention itself, ${ }^{28}$ it did sign and ratify the 1967 UN Protocol Relating to the Status of Refugees ("Refugee Protocol"), which incorporates the terms of the Convention by reference. ${ }^{29}$ This non-refoulement obligation is extended by the Convention Against Torture and Other Cruel, Inhuman or Degrading Treatment or Punishment ("Convention Against Torture") to prohibit returning "a person to another State where there are substantial grounds for believing that he [or she] would be in danger of being subjected to torture." 30 The United States signed and ratified the Convention Against Torture by 1990, subject to various "reservations," "understandings," and "declarations." 31

The Convention carves out only two exceptions to the non-refoulement obligation: It does not protect refugees who (1) are a "danger to the security of the country" or (2) are a "danger to the community" due to conviction of a "particularly serious crime." ${ }^{32}$ Academics have long asserted that any other countervailing interests that the government may have, including "expediency and economy," "political considerations," or a general preference against criminals, do not exempt it from the fundamental obligation to protect the human right of nonrefoulement. ${ }^{33}$

Although the United States has ratified two treaties invoking the non-refoulement obligation, the mechanics by which the United States is bound by this obligation are ambiguous. The Senate Resolution of

28. See U.N. High Comm'r for Refugees, State Parties to the 1951 Convention Relating to the Status of Refugees and the 1967 Protocol, https:// www.unhcr.org/protect/PROTECTION/3b73b0d63.pdf [https://perma.cc/VWW5U5U2].

29. Ramji-Nogales, supra note 26; Protocol Relating to the Status of Refugees, Jan. 31, 1967, 606 U.N.T.S. 267.

30. G.A. Res. 39/46 pt. 1, art. 3, United Nations Convention Against Torture and Other Cruel, Inhuman or Degrading Treatment or Punishment (Dec. 10, 1984).

31. S. TREaty Doc. No. 100-20 (1990), https://www.congress.gov/treaty-document/100th-congress/20/resolution-text [https://perma.cc/948D-TQ66].

32. U.N. Convention, supra note 26, art. 33(2).

33. See Kathleen M. Keller, A Comparative and International Law Perspective on the United States (Non)Compliance with Its Duty of Non-Refoulement, 2 YAle Hum. RTs. \& Dev. L.J. 183, 184 (1999) (“The United State[s'] interest in expediency and economy pale in comparison with the importance of the fundamental human rights norm of non-refoulement embodied by the Refugee Convention."); Scott M. Martin, Non-Refoulement of Refugees: United States Compliance with International Obligations, 7 Immigr. \& NAT'y L. ReV. 650, 670 (1982) ("The progress of Congress and the courts toward fuller recognition of the principle of non-refoulement is appropriate and desirable. Especially important is more careful judicial review . . . since political considerations may undermine the executive branch's observance of the non-refoulment principle."); Shirley Llain Arenilla, Violations to the Principle of Non-Refoulement Under the Asylum Policy of the United States, 15 Anuario Mexicano de DeRECHo InTERnACIONAL 283, 311 (citing a UNHCR opinion, which states that denying withholding due to conviction of a "particularly serious crime" without a separate "danger to the community" assessment is "contrary to United State[s'] obligations under international law" and "contrary to the spirit, purpose and requirements of Article 33(2)" of the Convention) (citation omitted). 
Ratification of the Convention Against Torture contains an express provision that Articles 1 through 16, which include the non-refoulement provision, are not self-executing; therefore, the Convention Articles had no legal effect in the U.S. judicial system until subsequent legislation and regulation implemented them. ${ }^{34}$ There is no such language accompanying the Senate Resolution of Advice and Consent to Ratification of the Refugee Protocol; ${ }^{35}$ however, there is evidence that the courts did not view the treaty as directly enforceable, at least insofar as enforceability would require substituting their "independent judgment" for the statutorily granted discretionary power of the Attorney General to effectuate or withhold removal. ${ }^{36}$ Courts repeatedly held that the ratification of the Refugee Protocol did not mandate changes in U.S. immigration law. ${ }^{37}$

It took an act of Congress, the Refugee Act of $1980,{ }^{38}$ to officially align the Immigration and Nationality Act ("INA") with the Refugee Protocol's non-refoulement obligation. ${ }^{39}$ The INA was amended to prohibit removal of an individual to a country "if the Attorney General determines that such alien's life or freedom would be threatened in such country on account of race, religion, nationality, membership in a particular social group, or political opinion," 40 a change that was "based directly upon the language of the [Refugee] Protocol and that ... [was] intended ... [to] be construed consistent with the Protocol." ${ }^{41}$ In I.N.S. v. Stevic, the Supreme Court affirmed this interpretation and suggested that non-refoulement was an obligation that existed before codification. ${ }^{42}$ The 1996 Illegal Immigration Reform and Immigrant Responsibility Act ("IIRIRA") relocated this provision within the INA, but the obligation remains the same. ${ }^{43}$

34. See S. Treaty Doc. No. 100-20; Frederic L. Kirgis, International Agreements and U.S. Law, ASIL InsigHTs (May 27, 1997), https://www.asil.org/insights/volume/2/ issue/5/international-agreements-and-us-law [https://perma.cc/4KR2-H4FY]. For a full discussion of the implementation of the CAT non-refoulement obligation, see Samuel L. David, A Foul Immigration Policy: U.S. Misinterpretation of the Non-Refoulement Obligation Under the Convention Against Torture, 19 N.Y.L. ScH. J. Hum. RTs. 769, 795-804 (2003).

35. S. Treaty Doc. No. 90-27 (1968), https://www.congress.gov/treaty-document/ 90th-congress/27/resolution-text [https://perma.cc/9WCK-UP2F].

36. See Martin, supra note 33, at 664-66.

37. Id. at 666 .

38. Refugee Act of 1980, Pub. L. No. 96-212, § 101, 94 Stat. 102 (1980) (codified in scattered sections of 8 U.S.C.).

39. See Martin, supra note 33, at 662-63.

40. Id. at 662 (quoting Refugee Act of 1980, 8 U.S.C. $\S 1231(\mathrm{~b})(3)(\mathrm{A})$.

41. Id. at 663 (quoting H.R. ReP. No. 96-781, at 20 (1980) (Conf. Rep.), as reprinted in 1980 U.S.C.C.A.N. 160, 161).

42. I.N.S. v. Stevic, 467 U.S. 407, 415, 421 (1984); see also Keller, supra note 33, at 194-95 (explaining further that the Court's opinion in Stevic shows an understanding that the United States' non-refoulement obligation predated codification).

43. Pub. L. No. 104-208, § 241(b)(3)(A), 110 Stat. 3009-602 (1996) (codified at 8 U.S.C. $\$ 1231(\mathrm{~b})(3)(\mathrm{A})$ ) ("[T] country if the Attorney General decides that the alien's life or freedom would be 
External sources can be instructive in determining what practices are in line with the treaties' mandate. For example, the Committee Against Torture ("the Committee") is an international body that provides guidance on and monitors the implementation of the Convention Against Torture. ${ }^{44}$ The Committee has published a set of "best practices" that it recommends state parties adopt as "preventive measures against possible violations of the principle of "non-refoulement." "45 Some of the recommendations include "[p]roviding access of the person alleging previous torture that might be deported to a lawyer and free legal aid when necessary" and "[t]he right of appeal by the person concerned against a deportation order to an independent administrative or judicial body within a reasonable period of time from the notification of that order and with the suspensive effect of its enforcement." 46

\section{B. Overview of Asylum, Withholding of Removal, and the Convention Against Torture}

Persons in the United States or at its border who fear returning to their countries of origin typically seek to apply for asylum. Asylum is a discretionary form of immigration relief that may be available to an individual who qualifies as a "refugee," defined by the INA as "any person who is outside any country of such person's nationality ... and who is unable or unwilling to return to . . . that country because of persecution $^{47}$ or a well-founded fear of persecution on account of race, religion, nationality, membership in a particular social group, or

threatened in that country because of the alien's race, religion, nationality, membership in a particular social group, or political opinion."); see also Keller, supra note 33, at 195 ("The 1996 Illegal Immigration Reform and Immigrant Responsibility Act (IIRAIRA) changed the withholding provision, renaming it 'Restriction on Removal.' Nothing in the new law, however, indicated that the mandatory nature of the provision had changed.").

44. Committee Against Torture, Monitoring the Prevention of Torture and Other Cruel, Inhuman or Degrading Treatment or Punishment, U.N. Hum. RTs., https:// www.ohchr.org/EN/HRBodies/CAT/Pages/CATIntro.aspx [https://perma.cc/QU8HTN2T].

45. Committee Against Torture, Draft, General Comment No. 1 (2017) on the Implementation of Article 3 of the Convention in the Context of Article 22, U.N. Hum. RTs. 4 (Feb. 2, 2017), https://www.ohchr.org/Documents/HRBodies/CAT/GCArticle3/ CAT-C-GC-1.pdf [https://perma.cc/3Bpp-EGX7].

46. Id.

47. According to a 2019 training for USCIS officers, the contemplated harm must be "sufficiently serious to amount to persecution" (for example, more than mere "discrimination or harassment" or "brief detention without mistreatment"), but "persecution is a broader concept than threats to "life or freedom"" (economic and psychological harm may rise to the level of persecution). USCIS, RAIO DIRECTORate-Officer Training: Definition of Persecution and Eligibility Based on Past Persecution 11, 13, 18, 20 (Dec. 20, 2019), https://www.uscis.gov/sites/default/ files/document/foia/Persecution_LP_RAIO.pdf [https://perma.cc/A5S6-U833] (quoting Stevic, 467 U.S. at 428 fn. 22. 
political opinion." 48 This statutory definition limits asylum relief to those who fear harm based on one of the five protected grounds. Additionally, even those who fit the definition of a refugee may be barred from asylum for various reasons. ${ }^{49}$ The ultimate burden of proof for an asylum-seeker is to convince an IJ that they have a "wellfounded fear" of persecution, meaning that they have a genuine, subjective fear of persecution and that there is an objective, "reasonable possibility" that the persecution will actually occur. ${ }^{50}$ For individuals who can make it through all the statutory, regulatory, and judicial hoops, the rewards are great: Asylees are immediately eligible to work in the United States, may apply for permanent residence after being in the United States for one year, and may obtain derivative status for their spouses and children. ${ }^{51}$

For individuals who fear returning to their countries of origin but are denied asylum due to negative discretionary factors or statutory or regulatory bars, two types of immigration relief are available: (1) statutory withholding of removal and (2) withholding or deferral of removal pursuant to the Convention Against Torture. ${ }^{52}$ Unlike asylum, these forms of relief are not discretionary-any individual who qualifies receives relief. ${ }^{53}$ However, despite the mandatory nature and absence of non-criminal bars (such as failure to apply within one year of arrival to the United States), ${ }^{54}$ very few individuals actually receive this type of relief. ${ }^{55}$ This is because withholding and CAT protection are only available to individuals who can prove a very high risk of severe harm. ${ }^{56}$ (2020).

48. Immigration and Nationality Act (INA) § 101(a)(42), 8 U.S.C. § 1101(a)(42)

49. Bars to asylum include, among other things, firm resettlement in a third country, previous denial of asylum, participation in persecution of others, and conviction of a particularly serious crime. Exec. OfF. FOR IMMigr. Rev., DeP'T Of Just., FAct Sheet: Asylum and Withholding of Removal Relief Convention Against Torture Protections 2 (Jan. 15, 2009), https://www.justice.gov/sites/default/files/ eoir/legacy/2009/01/23/AsylumWithholdingCATProtections.pdf [https://perma.cc/ 8HX9-W9FB] [hereinafter FACT SHEET].

50. See 8 C.F.R. $\S 1208.13$ (b)(2)(i) (2021).

51. Benefits and Responsibilities of Asylees, USCIS, https://www.uscis.gov/humanitarian/refugees-and-asylum/asylum/benefits-and-responsibilities-of-asylees (Mar. 8, 2015) [https://perma.cc/UX43-WSK8].

52. FACt SHeEt, supra note 49 , at 5.

53. Immigr. Equal., Withholding of Removal-A Higher Standard, in Asylum MANUAL $\S 6.1$, https://immigrationequality.org/asylum/asylum-manual/immigrationbasics-withholding-of-removal/ [https://perma.cc/5NAQ-MH6W].

54. See Fact Sheet: Withholding of Removal and the U.N. Convention Against Torture-No Substitute for Asylum, Putting Refugees at Risk, Hum. RTs. First (Nov. 2018), https://www.humanrightsfirst.org/sites/default/files/CAT_Withholding.pdf [https://perma.cc/34T3-K88E] [hereinafter Withholding of Removal Fact Sheet].

55. Id. ("In fiscal year 2016, the immigration courts granted only $6 \%$ of withholding applications and less than $5 \%$ of adjudicated CAT cases.").

56. Id. 
Withholding, the United States' codification of the non-refoulement obligation, is available to refugees who can prove that they are more likely than not to be persecuted ${ }^{57}$ "on account of race, religion, nationality, membership in a particular social group, or political opinion." 58 CAT protection is available to individuals who can prove that it is more likely than not they will be tortured ${ }^{59}$ by their home country's government or with its acquiescence. ${ }^{60}$ As their names suggest, these types of relief are more limited than a grant of asylum. Withholding and CAT protection grantees may not be removed to the country where they have proven they would likely face future harm, but they may be removed to a third country. ${ }^{61}$ Additionally, there is no path to permanent residence, there is no automatic work authorization, and there is no grant of status or protection to family members. ${ }^{62}$ Finally, CAT protection may be temporary; if the Department of Homeland Security ("DHS") determines that the individual is no longer likely to be tortured, the protection may be terminated. ${ }^{63}$ Despite these limitations, withholding and CAT protection are important humanitarian safeguards, and their integrity must be preserved.

\section{Procedural Barriers: Expedited Removal Proceedings and Fear Screening Interviews}

Although asylum, withholding, and CAT protection protect fundamental interests and are legally and factually complex claims, noncitizens seeking this protection must overcome various hurdles before getting the opportunity to present their cases to a judge. ${ }^{64}$ All individuals lacking valid entry documents who present themselves at a U.S. port of entry (termed "arriving aliens") or who are "apprehended within 100 miles of the U.S. border within fourteen days" of entry, among other things, are subject to expedited removal proceedings pursuant to INA $\$ 235 .{ }^{65}$ This procedure allows removal of these undocumented individuals without a hearing or administrative review. ${ }^{66}$ Immigration advocates have long argued that expedited removal itself violates the United States' non-refoulement obligation. ${ }^{67}$ The only

57. For the purposes of withholding, persecution refers to a threat to the individual's "life or freedom." 8 C.F.R. § 208.16(b) (2021).

58. Id.; Withholding of Removal Fact Sheet, supra note 54.

59. Torture is severe pain or suffering that is intentionally inflicted. FACT SHEET, supra note 49 , at 7.

60. Id.; 8 C.F.R. $\S 208.17$ (a) (2021).

61. FACT SHEET, supra note 49 , at 6-7.

62. Id.

63. Id. at 8 .

64. See supra note 3 and accompanying text.

65. Immigration and Nationality Act (INA) § 235, 8 U.S.C. $\$ 1225$ (2020); SMITH, supra note 4 , at 2.

66. Smith, supra note 4, at 2.

67. See Michele R. Pistone \& John J. Hoeffner, Rules Are Made to Be Broken: How the Process of Expedited Removal Fails Asylum Seekers, 20 Geo. Immigr. L.J. 
way to pause this swift removal process is to express an intent to apply for asylum or a fear of persecution in a particular country. ${ }^{68}$ These asylum-seekers are then referred to a DHS asylum officer for what is generally referred to as a "credible fear interview." ${ }^{69}$ Here, the officer determines, based on their questioning of the asylum-seeker, whether the individual has shown a "significant possibility" of eligibility for asylum. ${ }^{70}$ Potential claims for withholding or CAT protection are also evaluated. ${ }^{71}$

If the individual receives a positive fear determination, they are placed in formal removal proceedings and remain in immigration detention during the pendency of the proceedings. ${ }^{72}$ An individual who receives a negative fear determination, meaning the DHS officer did not find it likely that they would qualify for asylum, withholding, or CAT protection, may seek review of their claim by an $\mathrm{IJ}^{73}$ If they do not affirmatively request administrative review or the IJ concurs with the negative fear determination, they are ordered removed and have no further procedural remedy. ${ }^{74}$

This process has received increased attention recently, both from those who wish to protect asylum-seekers ${ }^{75}$ and those who view asylum-seekers as "invaders." 76 This is likely due to the fact that "the overall percentage of [noncitizens] subject to expedited removal and referred ... for a credible-fear interview on claims of a fear of return has jumped from approximately [5\%] to above [40\%]" in the past decade. ${ }^{77}$ This increase is primarily because of an influx of migrants seeking refuge from violence and turmoil in Central America, particularly the three Northern Triangle countries: Guatemala, Honduras, and El Salvador. ${ }^{78}$ Allegedly to mitigate the strain on the U.S. immigration

167, 170 (2006). Over one hundred organizations, including Amnesty International USA and Human Rights Watch, have called for the Biden Administration to rescind the expedited removal policy. Over 100 Groups Urge Biden to Fully Rescind Title 42 Expulsions, Hum. RTs. WATCH (June 30, 2021, 8:00 AM), https://www.hrw.org/news/ 2021/06/30/over-100-groups-urge-biden-fully-rescind-title-42-expulsions\# [https:// perma.cc/XZ5R-Z99U].

68. SMith, supra note 4, at 2.

69. Id.; CASSIDY \& LYNCH, supra note 9, at 11-12.

70. Exec. Off. for Immigr. Rev., U.S. Dep'T of Just., EOIR Policy Manual $\S 7.4(\mathrm{~d})(1)$, https://www.justice.gov/eoir/eoir-policy-manual/7/4 (Jan. 10, 2021) [https:// perma.cc/FRH3-BKMH].

71. Sмiтh, supra note 4 , at 2.

72. $I d$. at $2-3$.

73. Id. at 3.

74. Id.

75. See, e.g., CAssidy \& LynCH, supra note 9, at 11-12.

76. See, e.g., Fritze, supra note 10.

77. Asylum Eligibility and Procedural Modifications, 84 Fed. Reg. 33,829, 33,830-31 (July 16, 2019) (codified at 8 C.F.R. $§ \$ 208,1003,1208$ ).

78. See Katherine Shattuck, Comment, Preventing Erroneous Expedited Removals: Immigration Judge Review and Requests for Reconsideration of Negative Credible Fear Determinations, 93 WAsh. L. REv. 459, 467 (2018); Scott Rempell, Credible Fears, Unaccompanied Minors, and the Causes of the Southwestern Border Surge, 18 
system created by the "large number of meritless asylum claims," regulators have introduced sweeping regulatory changes to the detriment of the many asylum-seekers with bona fide claims. ${ }^{79}$

\section{An Impermissible Threat to the Fulfillment of Non- Refoulement Obligations: Use of the "Reasonable Possibility" Standard in Initial Fear Screenings}

\section{A. Recent Attempts to Radically Change Asylum Regulations}

The Trump Administration led a wholesale attack on asylum-seekers during its four-year tenure. ${ }^{80}$ This Comment focuses on the clear intent to increase the standard of proof for a positive fear finding with respect to withholding and CAT protection. ${ }^{81}$ If the 2019 and 2020 rule changes were to be fully realized, noncitizens subject to expedited removal proceedings would have to meet the "reasonable possibility" standard of proof to have access to withholding of removal and CAT proceedings. ${ }^{82}$ Specifically, the standard requires that the individual demonstrate to the asylum officer (a) "a reasonable possibility that [they] would be persecuted" on account of their race, religion, nationality, membership in a particular social group, or political opinion in the country of removal, or (b) "a reasonable possibility that [they] would be tortured in the country of removal." 83 The standard of proof was previously the same as for asylum: a "significant possibility that the [individual] can establish . . . eligibility." $" 84$

Chap. L. Rev. 337, 340 (2015); António Guterres, Foreword to U.N. High Comm'r for Refugees, Women on the Run: First-Hand Accounts of Refugees Fleeing El Salvador, Guatemala, Honduras, and Mexico (2015), http:// www.unhcr.org/publications/operations/5630f24c6/women-run.html [https://perma.cc/ B8B5-GYYH].

79. See Asylum Eligibility and Procedural Modifications, 84 Fed. Reg. at 33,831.

80. See, e.g., How the Trump Administration Is Using COVID-19 to End Asylum, INT'L RESCUE COMM., https://www.rescue.org/article/how-trump-administration-using-covid-19-end-asylum (Sept. 16, 2020) [https://perma.cc/UZ6L-LDMR].

81. See Procedures for Asylum and Withholding of Removal; Credible Fear and Reasonable Fear Review, 85 Fed. Reg. 36,264, 36,268 (proposed June 15, 2020) (to be codified at 8 C.F.R. $\S \S 208,235,1003,1208,1235$ ) ("This rule also proposes clarifying and raising the statutory withholding of removal screening standard and the torturerelated screening standard under the CAT regulations for stowaways and aliens in expedited removal.").

82. Id. at 36,269 .

83. Id. (emphasis added).

84. Id. at 36,268 (emphasis added). 
Currently, only the 2019 regulatory changes have gone into effect. ${ }^{85}$ The 2020 Final Rule was set to go into effect on January 11, 2021, ${ }^{86}$ but on January 8, 2021, a judge in the U.S. District Court for the Northern District of California granted a preliminary injunction suspending the implementation of the rule pending proceedings challenging the rule. ${ }^{87}$ Now that the Biden Administration is in power, the fate of this rule is uncertain. However, it should be noted that the provision expanding the use of the reasonable possibility standard for fear screenings was not specifically challenged in the complaint associated with the preliminary injunction. ${ }^{88}$ Even if this particular rule is abandoned or defeated in litigation, it is vital to explore the legality of the provisions lest they reappear in subsequent administrations.

\section{B. The "Reasonable Possibility" Standard Explained}

The reasonable possibility standard of proof is not appropriate for use in initial fear screenings, and this is best illustrated by comparison with the "significant possibility" standard, which was designed for threshold screenings. ${ }^{89}$ First, while the linguistic effect of a change from "significant" to "reasonable" is ambiguous at best, ${ }^{90}$ the legal effect is clear and harmful. Second, interpreting the language of the standards indicates that the reasonable possibility standard requires the officer to make a determination on the merits regarding the possibility of persecution or torture itself, whereas the significant possibility standard requires only speculation as to what the individual might establish at a future hearing.

The significant possibility standard requires that the individual seeking relief "demonstrate a substantial and realistic possibility of succeeding" in immigration court. ${ }^{91}$ This is meant to be a low screen-

85. The 2019 Interim Final Rule became effective on July 16, 2019. Asylum Eligibility and Procedural Modifications, 84 Fed. Reg. 33,829, 33,830 (July 16, 2019) (codified at 8 C.F.R. $\S \S 208,1003,1208)$.

86. Procedures for Asylum and Withholding of Removal; Credible Fear and Reasonable Fear Review, 85 Fed. Reg. 80,274, 80,274 (Dec. 11, 2020) (codified at 8 C.F.R. $\S \S 208,235,1003,1208,1235)$.

87. Pangea Legal Servs. v. Dep't of Homeland Sec., 512 F. Supp. 3d 966, 969 (N.D. Cal. 2021).

88. Complaint for Declaratory and Injunctive Relief, Immigr. Equal. v. Dep't of Homeland Sec., No. 3:20-cv-09258, Doc. 1 (N.D. Cal. Dec. 21, 2020).

89. See USCiS, Asylum Officer Basic Training: Asylum Eligibility Part IV: Burden of Proof, Standards of Proof, and Evidence, Am. Immigr. Laws. Ass'N 11-13 (Sept. 14, 2006) (citing 142 Cong. Rec. S11491-02 (Sept. 27, 1996) (Statement of Sen. Orrin Hatch)), https://www.aila.org/infonet/aobt-lesson-burden-standards-proof-evidence [https://perma.cc/YK7E-JJD8] [hereinafter STANDARDS OF Proof TRAINING].

90. See Procedures for Asylum and Withholding of Removal; Credible Fear and Reasonable Fear Review, 85 Fed. Reg. 36,264, 36,268 (proposed June 15, 2020).

91. See USCIS, RAIO Directorate Asylum Division Officer Training Course: Credible Fear of Persecution and Torture Determinations 12 (Apr. 30, 2019) (emphasis omitted), https://www.uscis.gov/sites/default/files/docu- 
ing standard. ${ }^{92}$ While asylum officers are instructed that more than a "mere possibility of success" is required, they are specifically told that this standard is lower than a preponderance of the evidence. ${ }^{93}$ The majority of the evidence need not establish the individual's entitlement to asylum, withholding, or CAT protection at this stage. ${ }^{94}$

The reasonable possibility standard is explicitly higher than the significant possibility standard. ${ }^{95}$ Although lower than the "more likely than not" standard, which is used for the ultimate adjudication of withholding and CAT adjudication claims, ${ }^{96}$ the reasonable possibility standard is not a low screening standard. ${ }^{97}$ On the contrary, it is "the same standard required to establish eligibility for asylum (the 'wellfounded fear' standard)." 98 To show a reasonable fear of persecution, the individual must establish "that the harm [feared] must be serious enough to be considered persecution," whereas "in the credible fear context ... the applicant need only demonstrate a significant possibility that [the applicant] could establish that the feared harm is serious enough to constitute persecution." 99 The harm must not only be serious but also reasonably likely to occur. ${ }^{100}$

This standard is lower than the "preponderance of the evidence" standard, but officers may not be properly trained to distinguish between the two. ${ }^{101}$ One training course, when discussing the reasonable possibility standard, instructs that the asylum officer "should consider whether a preponderance of the evidence shows that a reasonable person in the applicant's circumstances would fear persecution."102 This standard leaves no room for inferences in the noncitizen's favor about what evidence could be available in the future at a full hearing. Instead, the officer must make a finding regarding the chances of fu-

ment/lesson-plans/Credible_Fear_of_Persecution_and_Torture_Determinations.pdf [https://perma.cc/AB7Q-W8MU] [hereinafter Credible Fear Training].

92. Standards of Proof Training, supra note 89, at 13.

93. Credible Fear Training, supra note 91, at 12.

94. Id.

95. USCiS, RaiO Directorate Asylum Division Officer Training Course: Reasonable Fear of Persecution and Torture Determinations 11 (Feb. 27, 2017), https://www.uscis.gov/sites/default/files/document/lesson-plans/Reasonable_ Fear_Asylum_Lesson_Plan.pdf [https://perma.cc/WE47-BKNP].

96. Id.

97. See id.

98. Id.

99. Id. at 17.

100. Id. The Supreme Court has suggested that a one-in-ten chance of future persecution would satisfy the reasonable possibility standard. I.N.S. v. Cardoza-Fonseca, 480 U.S. 421, 440 (1987).

101. USCIS, Evidence, in RAIO Directorate-OfFicer Training 209 (Aug. 3, 2015), https://www.uscis.gov/sites/default/files/document/foia/RAIO_Directorate_Officer_Training_Manual.pdf [https://perma.cc/9JE2-A75W].

102. Id. 
ture persecution or torture based on the evidence presented in the interview. ${ }^{103}$

\section{Same Standard, Vastly Different Protections and Resources: A Comparison of the Asylum Merits Hearing and the Fear Screening Interview Setting}

The potential for increased use of the reasonable possibility standard in fear screening interviews brings to the forefront the issues associated with using a standard suitable for final determinations on the merits at the initial screening stage. This standard has been previously used for reasonable fear interviews, which are the initial screenings for individuals who have been previously removed from the United States and have returned to present new fear-based claims. ${ }^{104}$ However, these individuals composed only a small minority of those receiving fear screenings. ${ }^{105}$ Thus, the reasonable possibility standard has historically been primarily used for final asylum adjudication, and this should remain the case. ${ }^{106}$

The setting and procedures used to elicit evidence related to fearbased claims are more significant than one might initially assume. This is because individuals seeking asylum, withholding, or CAT protection, perhaps at a higher incidence than almost any other group navigating the U.S. judicial system, have by definition experienced extreme trauma, and the grant or denial of relief hinges on how convincingly they can convey that trauma to a stranger. ${ }^{107}$ Research has shown that trauma and cultural norms affect both how individuals record their experiences and how they recount them. ${ }^{108}$ These factors make it easy for individuals trying to navigate a novel legal landscape to fail.

103. See id.

104. 8 C.F.R. $\$ 1208.31$ (2021).

105. For example, in January 2020, received reasonable fear interviews constituted less than $18 \%$ of all fear screenings $(1,027$ compared to 4,778 credible fear interviews). Semi-Monthly Credible Fear and Reasonable Fear Receipts and Decisions by Outcome Type: December 16, 2019 to December 31, 2020, USCIS (Jan. 6, 2021) [hereinafter Fear Decisions Data] (on file with author).

106. U.S. immigration courts decided approximately 9,700 asylum cases in January 2020. Asylum Decisions, TRAC IMMIGRATION, https://trac.syr.edu/phptools/immigration/asylum/ [https://perma.cc/4NV2-J42R].

107. See Jane Herlihy et al., Just Tell Us What Happened to You: Autobiographical Memory and Seeking Asylum, 26 Applied Cognitive Psych. 661, 662 (2012); Kathryn Shepherd \& Royce Bernstein Murray, Am. Immigr. Council, The Perils of Expedited Removal: How Fast-Track Deportations Jeopardize AsYlum SEEKERS 9 (2017), https://www.americanimmigrationcouncil.org/sites/default/files/research/the_perils_of_expedited_removal_how_fast-track_deportations_ jeopardize_detained_asylum_seekers.pdf [https://perma.cc/9GVC-3KNQ].

108. SHEPHERD \& MURRAY, supra note 107 , at 9. 


\section{Procedural Safeguards at the Asylum Merits Hearing}

While procedural safeguards in immigration courts are still much weaker than those afforded to defendants in criminal proceedings, the asylum merits hearing is intended to provide the noncitizen facing deportation with "a full and fair hearing of [their] claims and a reasonable opportunity to present evidence on [their] behalf." 109

Although the government will not provide an attorney, individuals in immigration court "have the privilege of being represented" by an attorney at their expense. ${ }^{110}$ Being represented by counsel is associated with drastically higher rates of success in immigration court, particularly when the noncitizen is detained, as most asylum-seekers affected by these rule changes are. ${ }^{111}$ The U.S. Government Accountability Office has gone as far as to say that "[r]epresentation generally doubled the likelihood of affirmative and defensive cases being granted asylum." 112 Additionally, the individual is entitled to "a reasonable opportunity to examine the evidence against [them], to present evidence on [their] own behalf, and to cross-examine witnesses presented by the Government." 113

Finally, individuals who are denied asylum by the IJ have the right to appeal. ${ }^{114}$ First, the individual must exhaust their administrative remedies and appeal to the Board of Immigration Appeals ("BIA"). ${ }^{115}$ If the BIA denies relief, the individual may seek review of their case by the judicial branch by appealing the BIA's decision to the United States Court of Appeals. ${ }^{116}$ If the Circuit Court affirms the

109. See Colmenar v. I.N.S., 210 F.3d 967, 971 (9th Cir. 2000).

110. 8 U.S.C. $\S 1362$.

111. Ingrid Eagly \& Steven Shafer, Am. Immigr. Council, Access to CounSEL IN IMMIGRATION COURT 1, 2 (2016), https://www.americanimmigrationcouncil. org/sites/default/files/research/access_to_counsel_in_immigration_court.pdf [https:// perma.cc/UP86-F5HP].

112. U.S. Gov't Accountability Off., GAO-08-940, U.S. Asylum System: SigNificant VARiation Existed in Asylum Outcomes Across ImMigration COURTS AND Judges 30 (2008), https://www.gao.gov/assets/gao-08-940.pdf [https:// perma.cc/7AHD-GM54]; see also Jaya Ramji-Nogales et al., Refugee Roulette: Disparities in Asylum Adjudication, 60 StAN. L. Rev. 295, 340 (2007) (reporting that represented asylum seekers "were granted asylum at a rate of $45.6 \%$, almost three times as high as the $16.3 \%$ grant rate for those without legal counsel"); Doe v. Wolf, 432 F. Supp. 3d 1200, 1213 (S.D. Cal. 2020) (recognizing the importance of counsel in a nonrefoulement interview).

113. 8 U.S.C. $\S 1229 \mathrm{a}(\mathrm{b})(4)(\mathrm{B})$.

114. Florence Immigrant \& Refugee Rts. Project, Appealing Your Case TO THE BoARd of IMMIGRATION APPEAls 4 (May 2013), https://firrp.org/media/BIAAppeal-Guide-2013_new-BIA-address-2013.pdf [https://perma.cc/2WNG-JPGG].

115. 8 U.S.C. $\S 1252(\mathrm{~d})(1)$ (requiring exhaustion of administrative appeals); 8 C.F.R. $§ 1003.1(b)$ (2021) (proscribing the BIA's appellate jurisdiction).

116. 8 U.S.C. $\$ 1252(\mathrm{~b})(2)$ ("The petition for review shall be filed with the court of appeals for the judicial circuit in which the immigration judge completed the proceedings."). Note, however, that at this point in the appeals process, the individual becomes deportable unless the Court of Appeals grants a stay of removal. See 8 U.S.C. $\S 1252(\mathrm{~b})(3)(B)$; Trina Realmuto et al., Practice Advisory: Seeking a Judicial Stay of 
BIA's decision, the individual may petition the Supreme Court for a writ of certiorari. ${ }^{117}$

\section{Problems with the Fear Screening Interview Setting}

Although the regulations governing fear screening interviews have provisions intended to ensure the officer can "elicit all relevant and useful information bearing on whether the applicant has a credible fear of persecution or torture," 118 it is well documented that these procedures, even if followed, are insufficient. ${ }^{119}$ This Section highlights some of the many known problems with fear screening interviews by asylum officers, including asylum-seekers' lack of understanding of the legal process, their limited access to counsel, and asylum officers' inconsistent application of procedures.

Various factors make it very difficult for asylum-seekers to obtain digestible legal information and representation before their fear screening interviews. Asylum-seekers in expedited removal proceedings are almost all detained, typically from the moment they enter the United States and often in remote, rural areas. ${ }^{120}$ Even those who are able to obtain attorneys experience difficulty in consulting with them. ${ }^{121}$ Lawyers of detained clients report restricted access and changing rules, and a recent lawsuit alleges that Customs and Border Protection ("CBP") does not "allow attorneys representing persons in its custody to visit such persons for the purpose of confidential legal advice." 122 The lawsuit further alleges that CBP has "a policy and practice of denying requests for in-person visits or confidential telephonic communication with counsel at its holding facilities" and that "lawyers are unable to locate, visit[,] or make confidential phone calls with their clients." 123

Those who are unable to obtain counsel must rely on information provided by $\mathrm{CBP}$ or Immigration and Customs Enforcement ("ICE"). ${ }^{124}$ CBP is required to give a document explaining the credible fear process to individuals who express a fear of return, but this form contains confusing terminology and is often not provided in the individual's native language. ${ }^{125}$ Even among those who receive a form in their language, many still do not understand the process they are

Removal in the Court of Appeals, Am. Immigr. Council 1-2 (2014), https:// www.americanimmigrationcouncil.org/sites/default/files/practice_advisory/seeking_a_ judicial_stay_of_removal_fin_1-21-14.pdf [https://perma.cc/M2AA-84Q9].

117. See 28 U.S.C. $\$ 2101(\mathrm{c})$.

118. 8 C.F.R. $\$ 208.30(\mathrm{~d})(2021)$.

119. See CAssidy \& LyNCH, supra note 9, at 56-60.

120. Id. at 54,69 .

121. Id. at 53; Doe v. Wolf, 432 F. Supp. 3d 1200, 1215 (S.D. Cal. 2020).

122. CAssidy \& LynCH, supra note 9, at 53; Wolf, 432 F. Supp. 3d at 1215.

123. Wolf, 432 F. Supp. 3d at 1215.

124. CASSIDY \& LyNCH, supra note 9, at 50-52.

125. Id. at 50 . 
about to face. ${ }^{126}$ Some additional trainings are available in ICE detention, but there are still significant educational and linguistic barriers that impede understanding. ${ }^{127}$ Finally, the U.S. Citizenship and Immigration Services ("USCIS") asylum officer at the credible fear interview verifies that the individual has received information on the process. ${ }^{128}$ While this may be sufficient to inform an educated individual with a straightforward case, it is unreasonable to expect detained individuals with low education, trauma, and possible health conditions to understand complicated legal concepts such as "nexus" or "particular social group" no matter how many pamphlets they are given. ${ }^{129}$

Once the asylum-seeker reaches the fear screening interview, armed with whatever information they have managed to absorb, technology can create further barriers to effective communication. The percent of credible fear interviews taking place telephonically increased from $2 \%$ in 2009 to $59 \%$ in 2014, with the greatest prevalence of telephonic interviews among "asylum seekers in Expedited Removal who crossed the southern border." 130 This presents a myriad of concerns. First, regulations dictate that interviews may be rescheduled if the noncitizen is "unable to participate effectively in the interview because of illness, fatigue, or other impediments," but these impediments may not be apparent over the phone. ${ }^{131}$ Additionally, legal service providers reported that telephonic interviews were "shorter, less accurate, and more confusing than in-person interviews." ${ }^{32}$ In-person follow-ups were initially required when a telephonic interview resulted in a negative fear finding, but this practice was discontinued in 2013. ${ }^{133}$ Even when the interview is conducted in person, translators almost always appear telephonically, creating similar concerns. ${ }^{134}$

The problems do not end there. Asylum officers are instructed to conduct interviews in a "nonadversarial manner" and to "elicit all relevant and useful information." 135 However, confidentiality concerns, improper demeanor, and failure to give family members the opportunity to interview privately also prevent many asylum-seekers from revealing sensitive but vital portions of their stories. ${ }^{136}$ One woman explained as follows:

I did not understand during the interview that the things I told the officer would remain confidential. My two older children are still

126. See id.

127. Id. at $50-51$.

128. Id. at 51 .

129. See Shepherd \& Murray, supra note 107, at 16-17.

130. CAssidy \& LyNCH, supra note 9, at 36.

131. 8 C.F.R. $\S 208.30(d)(1)$ (2021).

132. CASSIDY \& LYNCH, supra note 9 , at 36.

133. Id. at 37.

134. See Shepherd \& Murray, supra note 107, at 20.

135. 8 C.F.R. $\S 208.30(d)$ (2021).

136. See Shepherd \& Murray, supra note 107, at 20-21. 
living in Honduras, and I was very worried during the interview that the gangs in my town in Honduras would find out what I had told the immigration authorities in the United States. I was worried that if I told the officer everything that happened, the gangs would hurt or kill my two children who remained in Honduras. Because I was so afraid for my other children, there were certain questions that I did not answer fully. ${ }^{137}$

There is also evidence of asylum-seekers failing to share important information because the asylum officer appeared disinterested, unbelieving, hurried, or aggressive. ${ }^{138}$ Guidance on interviewing children ${ }^{139}$ and victims of trauma ${ }^{140}$ are available to officers, but although training and quality control measures exist, they are not implemented and recorded reliably. ${ }^{141}$

Another woman, Isidora, explained that she received a negative fear finding because she left out parts of her story because her daughter, Daysi, was present. ${ }^{142}$ She explained as follows:

I didn't want to mention what was going on because we were interviewed together. My daughter was there, and I didn't want her to find out and fall into deeper depression.... I did not tell the officer about the [rape by Daysi's father] or the phone call [that I received from the gang members threatening to kill my daughter first and then end with me] because I did not want my daughter to hear about it, since she is having problems with her stomach and suffers with depression. ${ }^{143}$

Isidora ultimately received a positive fear finding on review by an $\mathrm{IJ},{ }^{144}$ but the proposed regulatory changes would make it harder for those similarly situated to receive such review. ${ }^{145}$ If the December 2020 rule changes were to go into effect, a negative fear finding at the interview stage would become final, and the asylum-seeker would be ordered removed unless the noncitizen were to affirmatively request

137. Id. at 20.

138. Id. at 21-22.

139. Id. at 22 .

140. USCIS, RAIO Combined Training Program: Interviewing Survivors of Torture and Other Severe Trauma (Nov. 25, 2015), https://www.uscis.gov/ sites/default/files/document/foia/Interviewing_-_Survivors_of_Torture_LP_RAIO.pdf [https://perma.cc/65TY-BN7S].

141. Shepherd \& Murray, supra note 107, at 21-22, 26; U.S. Gov't AcCountaBility OfF., GAO-20-250, Actions Needed to Strengthen USCIS's Oversight and Data Quality of Credible and Reasonable Fear Screenings 21-39 (2020), https://www.gao.gov/assets/710/704732.pdf [https://perma.cc/M5N4-XNXT].

142. Shephard \& MurRay, supra note 107 , at 21.

143. Id.

144. $I d$.

145. See Procedures for Asylum and Withholding of Removal; Credible Fear and Reasonable Fear Review, 85 Fed. Reg. 36,264, 36,273 (proposed June 15, 2020). 
review. ${ }^{146}$ Under current rules, the finding is forwarded for review by an IJ unless the noncitizen affirmatively declines review. ${ }^{147}$

These examples illustrate that the fear screening process is not as simple as it may appear. Detention, officer misconduct, and technology, among other things, all get in the way of noncitizens seeking protection being able to clearly and convincingly articulate their stories.

\section{Lack of Judicial Review}

Unlike in formal asylum merits proceedings, the individual who receives a negative fear determination has no right to appeal either to the BIA or to the federal courts. ${ }^{148}$ Not only are these fear determinations not directly appealable, but the IIRIRA restricts asylum-seekers' ability to avail themselves of the federal habeas statute. ${ }^{149}$ Specifically, 8 U.S.C. $\$ 1252$ dictates that "the determination" that an applicant lacks a credible fear of persecution may not be reviewed by the courts even when included in a petition for a writ of habeas corpus. ${ }^{150}$ The Supreme Court affirmed the constitutionality of this provision in $D e$ partment of Homeland Security v. Thuraissigiam. ${ }^{151}$

\section{Analysis: Expanded Use of the Reasonable Possibility Standard Violates the Non-Refoulement Obligation}

When proposing the expansion of the reasonable possibility standard to govern all requests for withholding and CAT protection at the fear screening stage, the government's essential argument was as follows: Because the standard of proof for a final determination of withholding and CAT protection is "a clear probability" or "more likely than not," a lesser, reasonable possibility standard at the interview stage is appropriate. ${ }^{152}$ Though logically appealing, this view is oversimplified-while it is true that the noncitizen must eventually meet this higher more likely than not burden at a full evidentiary hearing ${ }^{153}$ the lack of resources and procedural safeguards available to the noncitizen at the fear screening stage make application of the reasonable possibility standard so early in the process impermissible.

Moreover, the use of the reasonable possibility standard for fear screenings is at odds with the congressional intent to honor the Refu-

146. $I d$.

147. $I d$.

148. 8 U.S.C. $\S 1252(a)(2)(A)$ (enumerating matters not subject to judicial review).

149. $I d$.

150. Id.

151. Dep't of Homeland Sec. v. Thuraissigiam, 140 S. Ct. 1959, 1963-64 (2020).

152. Procedures for Asylum and Withholding of Removal; Credible Fear and Reasonable Fear Review, 85 Fed. Reg. at 36,269.

153. See 8 C.F.R. $\S 1208.16(b)(2)$, (c)(2) (2021); 8 C.F.R. $\$ 1208.17(a)$ (2021); see also E. Bay Sanctuary Covenant v. Trump, 950 F.3d 1242, 1277 (9th Cir. 2020) ("A 'clear probability' of persecution or torture means that it is 'more likely than not' that applicants will be persecuted upon their removal."). 
gee Protocol and CAT non-refoulement obligations and with international law, as it increases the risk that individuals will be returned to their home countries and face persecution, torture, or death. It is instructive to look to Innovation Law Lab v. Wolf where the Ninth Circuit considered the non-refoulement obligation when analyzing the legality of a fear screening procedure. ${ }^{154}$ The court first asserted that the non-refoulement obligation does apply at the fear screening stage, holding that "Article 33 [of the Refugee Convention] is a general antirefoulement provision, applicable whenever an alien might be returned to a country where his or her life or freedom might be threatened on account of a protected ground." ${ }^{55}$ At issue, among other thins, was the use of the more likely than not standard at the fear screening stage. ${ }^{156}$ The court noted that the more likely than not standard is usually only applied at a full removal hearing and is much higher than the typical fear screening standard-significant possibility. ${ }^{157}$ Considering the use of this high screening standard and the lack of other procedural safeguards, the court held that the procedure likely violated the United States' non-refoulement obligation. ${ }^{158}$

A similar analysis leads to the conclusion given the insufficient procedural safeguards in place in fear screening interviews, the use of the reasonable possibility standard violates the non-refoulement obligation. Although the standard in question here, reasonable possibility, is not as high as the more likely than not standard, it is still higher than the normal fear screening standard and is normally used at a full removal hearing. ${ }^{159}$ As detailed above, the fear screening process is fraught with problems that prevent individuals from having their claims fairly assessed. ${ }^{160}$ Access to counsel at the fear screening stage is extremely limited, and representation is never provided at the government's expense. ${ }^{161}$ Information provided to unrepresented individuals on the legal process and standards of proof is limited and difficult to understand. ${ }^{162}$ The increased use of technology and the inconsistency of asylum officers often create an environment that, instead of fostering trust and openness, keeps fearful and traumatized individuals from sharing the most important aspects of their claims. ${ }^{163}$ These problems alone create a risk that individuals will wrongfully receive negative fear determinations and be removed to subsequently face

154. Innovation L. Lab v. Wolf, 951 F.3d 1073 (9th Cir. 2020), vacated as moot sub nom. Innovation L. Lab v. Mayorkas, 5 F.4th 1099 (9th Cir. 2021).

155. Id. at 1089 .

156. $I d$. at 1088 .

157. Id. at $1088-89$.

158. Id. at 1089 .

159. See supra Part III.

160. See supra Section III.C.2.

161. See supra Section III.C.2.

162. See supra Section III.C.2.

163. See supra Section III.C.2. 
persecution, torture, or death. This risk is substantially exacerbated by the almost nonexistent right to appeal and the complete insulation of these determinations from review by a truly neutral decisionmaker such as a federal judge. ${ }^{164}$ These problems, particularly the restricted access to counsel and appeal, result in the United States falling short of the Committee Against Torture's recommended best practices at the fear screening stage. ${ }^{165}$ Thus, the standard of proof cannot be raised without further jeopardizing compliance with the non-refoulement obligation.

A comparison of grant rates in credible versus reasonable fear interviews illustrates that the difference in standards creates a real, practical difference in results. Currently, credible fear interviews employ the significant possibility standard to screen for fear of persecution or torture in one's country of origin. ${ }^{166}$ Reasonable fear interviews, using the reasonable possibility standard, are given to individuals barred from applying for asylum, particularly because they have previously been ordered removed from the United States. ${ }^{167}$ Despite the statistic quoted by the Supreme Court in Thuraissigiam that "[o]ver the last five years, nearly $77 \%$ of screenings have resulted in a finding of credible fear," 168 between December 16, 2019, and December 31, 2020, only $39 \%$ of decisions from credible fear cases were positive. ${ }^{169}$ Over the same period, only $13 \%$ of reasonable fear determinations were positive. ${ }^{170}$ There is no reason to believe that individuals receiving credible fear interviews systematically have stronger fears of qualifying persecution or torture. Although some individuals are placed in reasonable fear interviews because of prior aggravated felony convictions, which can bar a grant of withholding of removal, "[a]sylum officers do not consider the mandatory bars to withholding of removal when making reasonable fear decisions," ${ }^{171}$ so this cannot explain the lower positive-fear rate. If anything, one may speculate that it might take a stronger fear to make an individual return when they have already been expelled and ordered not to return. Thus, using the reasonable possibility standard instead of the significant possibility standard likely accounts for fear being established only one-third as often in reasonable fear interviews.

164. See supra Section III.C.2.

165. See supra Section II.A.

166. 8 C.F.R. $\S 208.30(\mathrm{e})(1)(2021)$.

167. 8 C.F.R. $\S 208.31(a)$, (c) (2021).

168. Dep't of Homeland Sec. v. Thuraissigiam, 140 S. Ct. 1959, 1966 (2020).

169. Out of 21,774 decisions issued, only 8,558 cases established fear. Fear Decisions Data, supra note 105, at 10.

170. Only 875 out of 6,560 decisions established fear. $I d$.

171. Questions and Answers: Reasonable Fear Screenings, USCIS, https:// www.uscis.gov/humanitarian/refugees-and-asylum/asylum/questions-and-answers-reasonable-fear-screenings (June 18, 2013) [https://perma.cc/XL6S-BGBM]. 
Taken together, these factors make it likely that by continuing current practices and expanding the use of the reasonable possibility standard, the United States will expel individuals seeking refuge using summary process and return them to face persecution, torture, or death. This violates the non-refoulement obligation and is contrary to congressional intent to conform with this international norm.

\section{The Dire Need for Full Due Process Protections for Noncitizens Seeking Protection from Refoulement}

The constitutional guarantee that "no person shall . . . be deprived of life, liberty, or property, without due process of law"172 appears to be a clear, universal mandate. However, the application of due process rights is anything but straightforward. ${ }^{173}$ This is especially apparent with respect to the amount of due process to which noncitizens are entitled. The Supreme Court has declared that "[noncitizens] who have once passed through our gates, even illegally, may be expelled only after proceedings conforming to traditional standards of fairness encompassed in due process of law." ${ }^{174}$ However, the Court has insisted that for arriving asylum-seekers, regardless of actual physical presence in the United States, "the decisions of executive or administrative officers, acting within powers expressly conferred by Congress, are due process of law." 175

\section{A. The Entry Fiction Should Not Apply to Individuals Seeking Withholding and CAT Protection}

This denial of due process rights to "arriving aliens" is based on the plenary power of the Executive to exclude foreigners ${ }^{176}$ and the "entry fiction," the legal doctrine that states that "[noncitizens] seeking admission into the United States may physically be allowed within its borders pending a determination of admissibility, but . . . are legally considered to be detained at the border and hence enjoy limited protections under the Constitution." ${ }^{177}$ Because decisions regarding who to admit or exclude are "an incident of sovereignty belonging to the government of the United States," these determinations by the political branches are "conclusive upon the judiciary." 178

172. U.S. Const. amend. V.

173. See generally Richard H. Fallon, Jr., Some Confusions About Due Process, Judicial Review, and Constitutional Remedies, 93 Colum. L. Rev. 309 (1993).

174. Shaughnessy v. United States ex rel. Mezei, 345 U.S. 206, 212 (1953).

175. Dep't of Homeland Sec. v. Thuraissigiam, 14 S. Ct. 1959, 1982 (2020) (quoting Ekiu v. United States, 142 U.S. 651, 660 (1892)).

176. See Ping v. United States, 130 U.S. 581, 606-09 (1889) (The "Chinese Exclusion Case").

177. Zainab A. Cheema, Note, A Constitutional Case for Extending the Due Process Clause to Asylum Seekers: Revisiting the Entry Fiction After Boumediene, 87 Fordham L. Rev. 289, 306 (2018).

178. Ping, 130 U.S. at 606, 609. 
This stance is unacceptable with respect to seekers of withholding and CAT protections. Unlike other immigration benefits, including asylum, withholding and CAT protections are not privileges that an IJ has discretion to deny or that Congress can decide to revoke at any time as a matter of policy. ${ }^{179}$ Non-refoulement is an obligation created by domestic and international law. ${ }^{180}$ Flimsy due process for grants of initial admission may be acceptable, but stronger procedural protections are necessary when such fundamental life and liberty interests are at stake. Noncitizens fearing persecution or torture in their home countries have a statutory right to seek protection against refoulement regardless of whether they are in the interior of the United States or present themselves at the border. ${ }^{181}$ Thus, the entry fiction, while perhaps a permissible policy choice with respect to noncitizens whose admission is a matter of discretion, should not apply to individuals exercising their congressionally granted right to seek withholding and CAT protections.

Critics of the entry fiction and its effects on asylum-seekers or inadmissible individuals generally have argued that the functional approach to determining the reach of the Constitution that the Court used in Boumediene v. Bush ${ }^{182}$ can be used to extend due process protections to additional noncitizens. ${ }^{183}$ In Boumediene, Justice Kennedy emphasized that permitting the political branches to determine "when and where [the Constitution's] terms apply" would inappropriately give them the "power to switch the Constitution on or off at will." 184 The Court thus held that the Suspension Clause of the Constitution ${ }^{185}$ applied to noncitizens detained at Guantanamo Bay, and therefore these noncitizens had the right to file habeas petitions. ${ }^{186}$ In reaching this conclusion, the Court rejected a formalist approach focusing solely on territoriality and instead considered practical concerns relating to the detainees' citizenship, the location of detention, and practical obstacles to facilitating the right. ${ }^{187}$ Zainab A. Cheema applied this

179. See supra Section II.B.

180. See supra Section II.A.

181. See supra Section II.A.

182. Boumediene v. Bush, 553 U.S. 723 (2008).

183. Cheema, supra note 177, at 293; Charles Ellison, Extending Due Process Protections to Unadmitted Aliens Within the U.S. Through the Functional Approach of Boumediene, 3 Idaho Critical Legal Stud. J. 1, 5 (2010).

184. Boumediene, 553 U.S. at 732.

185. U.S. ConsT. art. I, $\S 9$, cl. 2 ("The privilege of the writ of habeas corpus shall not be suspended, unless when in cases of rebellion or invasion the public safety may require it.").

186. Boumediene, 553 U.S. at 765.

187. Id. at 766; see also Fatma E. Marouf, Extraterritorial Rights in Border Enforcement, 77 WASH. \& LeE L. Rev. 751, 785-86 (2020) (explaining how Justice Kennedy created this functional approach); Cheema, supra note 177, at 314 (explaining further the Court's rationale behind the functional approach). 
functional approach to arriving asylum-seekers ${ }^{188}$ and reached the following conclusion:

"Practical considerations" shaping the reach of the Constitution weigh heavily in favor of extending procedural due process protections: the inspection stations for U.S. ports of entry are clearly on U.S. territory, the ongoing detention of arriving aliens occurs at U.S. jails or prisons within the interior, and producing them for bond hearings neither damages the prestige of immigration authorities nor imposes a heavy burden on government resources. ${ }^{189}$

Although Cheema's analysis focused on bond hearings as the due process remedy, ${ }^{190}$ the analysis stands with respect to keeping fear screening standards low, as the burden on government resources is similarly light. ${ }^{191}$

The argument for extension is even stronger when considering the "fundamental rights approach," which although no longer the dominant approach, "continues to influence decisions implicitly." ${ }^{192}$ Under this approach, "[o]nce a right was determined to be fundamental, it was required regardless of any practical obstacles."193 These protected rights have been defined as being "fundamental in [the] international sense," relating to "shared beliefs of diverse cultures." ${ }^{94}$ As discussed above, non-refoulement is an accepted, fundamental international norm, ${ }^{195}$ and as such, constitutional due process for individuals seeking protection from refoulement should be considered fundamental under this approach and therefore unimpeachable.

\section{B. Application of the Mathews Due Process Test to the Proposed Fear Screening Procedures}

Affording more substantial due process rights to seekers of nonrefoulement protections is not a fringe or merely academic idea; Justice Sotomayor, for example, disagrees with the current framework. ${ }^{196}$ In her dissent to Thuraissigiam, Justice Sotomayor asserts her belief that "[a]s a noncitizen within the territory of the United States, [an asylum-seeker] is entitled to invoke the protections of the Due Process Clause" regardless of if the noncitizen entered the country legally or otherwise. ${ }^{197}$ She characterizes the denial of due process rights to

188. Cheema, supra note 177 , at 317-20.

189. Id. at 317.

190. Id. at 290.

191. See infra Section IV.B.

192. Marouf, supra note 187 , at 788.

193. Id. at 790.

194. Id. at 789-90 (quoting Wabol v. Villacrusis, 958 F.2d 1450, 1460 (9th Cir. 1990)).

195. See supra Section II.A.

196. Dep't Homeland Sec. v. Thuraissigiam, 140 S. Ct. 1959, 2012 (2020) (Sotomayor, J., dissenting).

197. Id. 
individuals "who challenge the procedures used to determine whether they may seek shelter in this country or whether they may be cast to an unknown fate" as "handcuff[ing] the Judiciary's ability to perform its constitutional duty to safeguard individual liberty." 198

This vital liberty interest Justice Sotomayor identified is why the Mathews v. Eldridge $e^{199}$ due process test should be applied in challenges to asylum procedure. Mathews lays out a three-prong balancing test to determine if the procedures in question are constitutionally sufficient. ${ }^{200}$ The factors weighed are:

(1) the private interest that will be affected by the official action; (2) the risk of an erroneous deprivation of such interest through the procedures used, and the probable value, if any, of additional procedural safeguards; and (3) the Government's interest, including the fiscal and administrative burdens that the additional or substitute procedures would entail. ${ }^{201}$

These factors can be applied when testing if the procedure afforded to individuals seeking withholding and CAT protection is constitutionally adequate.

The private interests at risk when an individual is seeking refuge in the United States are liberty from fear of persecution or torture and, ultimately, one's very life. These are the ultimate human rights and are the types of interests that fit most squarely within the Due Process Clause. In $N g$. White, a case not involving asylum, the Supreme Court acknowledged that deportation may result in "loss of both property and life, or of all that makes life worth living." ${ }^{202}$ For individuals seeking withholding or CAT protection, this chance of loss is greatly magnified. ${ }^{203}$ Some have even compared the interest to that of individuals facing the death penalty, arguing that the Supreme Court should remember its reasoning that "death is different" because of "its severity and its finality" when considering what protections to afford individuals who claim they will be killed if returned to their home country. ${ }^{204}$

Regarding the second Mathews factor, the risk of erroneous deprivation, the Court clarified that "procedural due process rules are shaped by the risk of error inherent in the truthfinding process as ap-

198. Id. at 1993.

199. Mathews v. Eldridge, 424 U.S. 319 (1976).

200. Id. at 321.

201. $I d$.

202. $\mathrm{Ng}$ v. White, 259 U.S. 276, 284 (1922).

203. For a discussion of the severity of persecution faced by asylum seekers, see Nimrod Pitsker, Due Process for All: Applying Eldridge to Require Appointed Counsel for Asylum Seekers, 95 CAL. L. REv. 169, 185-87 (2007).

204. John R. Mills et al., "Death is Different” and a Refugee's Right to Counsel, 42 CoRnell InT'L L.J. 361, 372-73 (2009) (quoting Gardner v. Florida, 430 U.S. 349, 357-58 (1977)). 
plied to the generality of cases, not the rare exceptions."205 The flaws in the fear screening process that make it systematically more difficult for individuals to demonstrate their fear of persecution or torture at the interview stage are well documented and are not "rare exceptions." ${ }^{206}$ Moreover, the application of the reasonable possibility standard will increase the risk of erroneous deprivation across the board. When only $13 \%$ of interviewees can prove a reasonable fear and only a third can prove a credible fear, ${ }^{207}$ the risk is clear: With the increased use of the reasonable possibility standard, many more individuals who fear for their lives will be unable to advance in the process. Additional time increases the likelihood that individuals will be able to access valuable resources such as evidence and legal advice before presenting their case to a judge. Denial at an early stage creates an impermissible risk that individuals who would have eventually been able to prove their claims will be removed-at their peril.

The burden on the government to not expand the use of the reasonable possibility standard is to keep operations as they are. While it is of course a burden on the immigration court system to process large numbers of asylum cases, it is not the case that under the significant possibility standard every individual who expresses any kind of fear will receive a full hearing. ${ }^{208}$ Less than half of credible fear decisions in 2020 were positive. ${ }^{209}$ So while the government's interest in reducing immigration court caseloads is legitimate, there are not floodgate concerns that would overcome the fundamental private interests that face a substantial risk of erroneous deprivation.

\section{Conclusion}

Immigration law regarding fear-based claims is moving in the wrong direction, putting vulnerable refugees at risk of persecution, torture, and death upon erroneous return to their home countries. Withholding and CAT protection must be safeguarded to avoid violating the non-refoulement obligation. Given the well-documented shortcomings of the fear screening process, requiring a higher standard of proof to be met at this early stage is impermissible. The reasonable possibility standard requires a determination on the merits and should be reserved for full hearings in immigration court. Additionally, the entry fiction that denies due process protections to individuals physically present in the United States while vindicating their rights pursuant to the non-refoulement obligation should be abandoned. These recommendations are justified because analysis of the Mathews procedural

205. Mathews, 424 U.S. at 344.

206. See supra Section III.C.2.

207. See supra notes $164-65$ and accompanying text.

208. Only 8,558 out of 21,774 decisions established fear. Fear Decisions Data, supra note 105 .

209. Id. 
due process test reveals that the government's interest in economy and efficiency is outweighed by the significant risk of erroneous deprivation of noncitizens' most fundamental human rights. 
